\title{
Uncertain mobilities: a view from the past
}

\author{
Colin G Pooley, Lancaster University
}

\begin{abstract}
Contemporary society assumes high levels of unimpeded mobility, and disruptions to the ability to move quickly and easily can cause considerable concern. ${ }^{1}$ This paper examines the notion of mobility uncertainty and disruption from an historical perspective, arguing that interruptions to mobility have long been a characteristic of everyday travel. It is suggested that what has changed is not so much the extent or nature of disruption, but rather the resilience of transport systems and societal norms and expectations about travel. Data are taken from five examples of life writing produced by residents of the United Kingdom during the nineteenth and early-twentieth centuries. The texts are used to illustrate the travel problems encountered and the strategies adopted to deal with them. A concluding discussion examines these themes in the context of $21^{\text {st }}$ century mobility.
\end{abstract}

\section{Key words}

Disruption, travel, resilience, diaries, weather, family, risk. 


\section{Introduction: continuity or change}

One implication of the 'new mobilities paradigm', ${ }^{2}$ however it is interpreted or applied, is that it must represent something new. This newness can be reflected in a number of different ways: how much and by what means we travel and communicate; the ways in which mobility is embedded in and productive of social, economic and cultural life; and the expectations that we have about which mobilities are available and what they deliver. ${ }^{3}$ Based on the premise that contemporary society has become increasingly mobility-dependent through both physical and virtual means of travel and communication, ${ }^{4}$ there has recently been increased attention focused on what happens when these mobilities are disrupted in some way. One event that drew particular attention to this problem was the Icelandic ash cloud in $2010,{ }^{5}$ but there are many other less dramatic ways in which the ability to move as and when one wishes can be disrupted on an everyday basis. These can include the impacts of extreme weather, industrial action, technological failures and family crises amongst other circumstances. ${ }^{6}$ As our lives become increasingly dependent on, and expectant of, unfettered mobility, locked within multiple systems of movement, adjusting to (temporary) immobility can prove problematic. ${ }^{7}$

Recent research has begun to explore the implications of immobility, the tensions between mobility and stability, how lack of access to physical or virtual mobilities can disrupt everyday lives, and how such events are accommodated and circumvented. ${ }^{8}$ In some cases this is constructed within a framework of practice theory, drawing on the work of Goffman and others on the practices of everyday life. ${ }^{9}$ Mobility disruptions can challenge normal expectations of how everyday life should function and thus create new problems of accommodation and circumvention. At the same time new forms of mobile communication allow instant access to information, alternative routes, contact with friends or relatives and, crucially, more control over many aspects of everyday life. ${ }^{10}$ In theory, this should make it easier to adjust schedules to cope with travel delays and disruptions, or to use technology to 
substitute for physical movement. ${ }^{11}$ However, there is only limited evidence that new forms of communication are actually reducing the demand for travel. ${ }^{12}$

This paper takes these contemporary trends as a starting point but adds a distinctive historical perspective. First, the extent and nature of travel in the past is examined: it is argued that although some things have changed there is also much continuity between the past and the present, and that not everything about twenty-first century mobility is new. Second, the paper explores the theme of mobility disruption and argues that rather than being a recent phenomenon the interruption of everyday mobility has been a normal part of travelling for most of history: dealing with disruption was an anticipated part of the practice of everyday movement. It is suggested that what have changed are the expectations that we place on mobility and, to some extent, the resilience of the systems of transport that we use, such that our everyday travelling practices now find it harder to accommodate uncertainty and disruption despite the availability of mobile communication systems. The paper uses selected examples to discuss these apparently contradictory trends in the context of travel and communication over the past two centuries. Although the evidence used in this paper is drawn from the United Kingdom the themes discussed have much wider application.

\section{The evidence}

Data used in this paper come from the analysis of a series of diaries and life histories that have been collected in the context of other research projects. These provide rich sources for studying everyday practices in the past, but there are a number of problems that must be borne in mind. First, diaries and life histories are two very different forms of life writing. The former should provide a more detailed day-to-day account whereas the latter provide an edited and constructed story about the author's life. Frequently these are constructed around a narrative of struggle and self-improvement, and are used to justify past actions. ${ }^{13}$ There are 
also gender differences in life writing with autobiographies and life histories most often written by men but diaries more often kept by (and surviving for) women. It can be argued that this reflects the different social roles occupied by men and women in the past, with life histories more in keeping with the public sphere of men and the more intimate diary form conforming to the private (domestic) sphere that most women were meant to inhabit. ${ }^{14}$ In all life writing we obviously only have information on those things that the authors chose to record: it can be suggested that the more immediate diary should provide a better record of everyday travel and its disruptions than the life history written later in life, when such events may have receded from the memory and may be viewed as much less significant than they were at the time. For these reasons I focus mainly on diary evidence, or on life histories clearly compiled from diaries.

Five main items of life writing are used in this paper, all written by residents of the United Kingdom: the Diary of Elizabeth Lee covering the period $1884-92,{ }^{15}$ the diary of Rhona Little (with most detail 1937-42), ${ }^{16}$ the 'diary' of John James (written as a life history from his diaries covering his life from 1822-1880), ${ }^{17}$ the life history of Henry Jaques (also written up from diaries) covering the period $1842-1900,{ }^{18}$ and the diary of Joseph Yates (1826-96). ${ }^{19}$ By definition diaries and life histories are written by those who are both literate and have the time to write. They rarely exist (or survive) for the poorest in society and are much more common among elites. The five writers used in this research, while not the poorest, were certainly not elite and could be seen to represent ordinary men and women from the skilled working class and the lower middle class. John James came from Cornwall and worked most of his life in mining as an engineer and (eventually) mine manager in both Cornwall and overseas; Henry Jaques was principally a shirt maker in the East End of London, but also worked as a travelling salesman for a London clothing company; and Joseph Yates was apprenticed at the age of 12 to be a clerk. Elizabeth Lee was the daughter 
of a Birkenhead (Merseyside) businessman who owned (with a partner) two gentlemans' outfitters in the town. In common with many women of her class she did not have paid employment but assisted in the shop from time to time and undertook domestic duties. Finally, Rhona Little left Northern Ireland as a teenager to take work as a typist in London where she lived throughout the period of the diary. They reflect experiences of travelling in many different locations over more than a century. In this paper selected extracts related to everyday travel are used to explore both the nature of movement and the extent and impact of disruptions to their everyday routines.

\section{Everyday travel in the past}

What do we know about everyday mobility in the past? Although some travel was obviously slower than today (though from the mid-nineteenth century travel by train provided relatively rapid transit over longer distances), it is clear that both the ability and expectation to be able to travel was firmly embedded in everyday social, economic and cultural life. In their different ways all the writers lived highly mobile lives. John James travelled extensively in England and also worked in at least six different countries; Henry Jaques moved freely around London and travelled over much of England in connection with his work; Elizabeth Lee travelled (often alone) over much of Merseyside and undertook longer journeys to visit family and for holidays and outings; and Rhona Little deliberately explored London on foot and by public transport after her arrival from Northern Ireland, and regularly made the journey back to her family. These themes are illustrated in a selection of extracts from the life history of Henry Jaques.

He spent his honeymoon at his aunt's house in the village of Shorne in Kent and described travelling some $42 \mathrm{~km}$ on foot and by train to London to supervise the completion 
of his new shop. The journey was tiring but mostly unproblematic apart from one occasion when he took a wrong turn:

During the 10 days spent at Shorne I had to make several trips to Mile End to help hasten on the completion of the shop. Leaving for London early in the morning and returning late at night, every time walking those weary four miles across the fields. One night I was later than usual. It was very dark and I took the wrong path, finally finding myself at Thorp I arrived at "Hanbury Cottage" at about $11 \mathrm{o} / \mathrm{c}$ having covered 7 miles instead of four. ${ }^{20}$

Later in life Jaques worked periodically as a buyer (in the tie department of a London firm), and also as a travelling salesman in both South-East England and further afield. A series of entries demonstrate the extent to which he travelled regularly, but also the fact that as he got older he found travel, and especially carrying a heavy bag of samples, tiring.

In the course of my business duties I had to go to many of the manufacturing centres in the northern provinces buying in most of the dry goods markets - Manchester, Glasgow, Belfast etc. ${ }^{21}$

The daily effort, involving long tedious walks between the many short drives by bus and train, the heavy weight of the bag, sometimes supplemented by a parcel in addition ... I rode as much as possible, but even the walk of a mile with a bag, parcel and umbrella made the work hard. ${ }^{22}$

Later in life, as Jaques became slightly more affluent, he also took regular holidays, usually travelling by trap and train in southern England. There is no sense from this life 
history, or from any of the other sources, that lack of transport prevented either social or work-related engagements and, although sometimes tiring, mobility was as central to the lives of these diarists as it is to most people today. As is the case today, most travel was unproblematic and trouble free. There is always a tendency for life writing to focus on the unusual, and this is certainly likely in life histories edited from diaries, but both of the female diarists were meticulous in recording what must have been almost all their activities as there was little unallocated time to do anything else. Thus we have a record of mundane trips to shop or visit friends alongside more exceptional journeys. It is clear from the accounts that travel on Merseyside in the 1880s and in London in the late 1930s was unproblematic for these women. They often travelled alone, frequently travelled late at night, and seemed relatively unconstrained in their mobility. This is, perhaps, especially noteworthy for Elizabeth Lee in the 1880 s when some accounts suggest that female mobility was restricted, ${ }^{23}$ and even after 1939 when London was first threatened with and then experienced bombing, Rhona Little continued to live and travel in London in a relatively unconstrained way. The following extracts provide just a small number of examples.

When she first arrived in London Rhona Little deliberately explored new routes and carefully recorded precisely where she went. On her second day at work in London she described her commute from the girls' hostel she was lodging in at Earl's Court to Holborn where she worked: "After that I went to the station. From there to Charing Cross. I walked through a little park, through Somerset House, across the road, through Bush House, up Aldwich to Kingsway and so to Holborn." 24 During air raids on London travel was obviously disrupted both by the blackout conditions and by the bombs themselves, but Rhona rarely allowed that to prevent her from going about her normal activities despite the obvious dangers, though at the height of the air raids diary entries do become much sparser. 
As a young, middle class woman growing up on Merseyside Elizabeth Lee had a great deal of freedom to travel for social activities, to meet friends, go to dances and return home late at night. The following two extracts (when she was aged 23/24) are typical:

May Burnett and I went together to a 'Cinderella' at the Tranmere Music Hall and enjoyed ourselves very much. ... . Got home about 1.a.m. very tired indeed. ${ }^{25}$ Very tired. Met Mr. P. Young at $4 \mathrm{pm}$. We went over to L'pool by boat, had tea at Kirkland's, then walked about a bit ... Had to leave Mr. Y. at the Central Station B'head, wish he could have come home with me, he is simply delightful. had some fun coming home. ${ }^{26}$

It is usually assumed that travel in the past was slower than it is today and that this therefore restricted movement. It is certainly the case that prior to the age of air transport international travel was much slower - it took John James 17 days to cross from Liverpool to New York in 1854 - but for much everyday movement the differences were smaller or nonexistent. In 1888 Elizabeth Lee travelled on the sleeper from Liverpool to London, leaving at 11.20pm and arriving at St Pancras at 6.00am; and in 1938 Rhona Little caught the overnight boat from Belfast to Heysham (arriving at $6.00 \mathrm{am}$ ) and was in London by $12.15 \mathrm{pm}$. In general, the shorter the distance travelled the less the difference in travel time compared to the present. Thus whereas it took approximately 50 times the current flying time to cross the Atlantic in the 1850 s, it only took three times the current travel time to go by train from Liverpool to London in the 1880s. Once in London travel on the underground or by bus would be easy. Current average speeds on the underground in central London are $20.5 \mathrm{mph}$ (including stops) with a maximum speed of $30-40 \mathrm{mph} .{ }^{27}$ Average speeds in the early twentieth century would only have been marginally slower. On busy urban roads there is 
even less difference. Despite the introduction of a congestion charge average travel speeds by road in central London today are only about $10 \mathrm{mph},{ }^{28}$ much the same as the speeds that could be achieved by a horse and carriage in the nineteenth century. Although in less congested locations cars can clearly travel much quicker, most large cities experience similar congestion for at least some periods and many towns are imposing $20 \mathrm{mph}$ speed limits on all residential streets. ${ }^{29}$ Thus improvements in travel time for everyday intra-urban travel are likely to be small. Certainly by the 1920 s motor buses and trams were travelling at speeds similar to those of urban traffic flows today. For short journeys undertaken on foot or by bike it is reasonable to assume that they were as fast and as easily accomplished as they are today. Given that both in the past and present most everyday travel was over short distances, ${ }^{30}$ it is argued that differences in travel speed between the past and present were less important than might be assumed.

Perhaps what has changed most are expectations of travel. For longer-distance travel in the pre-railway age it was normal for a journey to take several days and stops would be built into travel plans. From accounts of journeys at this time these were viewed as an unexceptional and anticipated part of travel. Thus in his life history Joseph Yates describes in a matter of fact fashion his journey from London to Leominster (Herefordshire), despite the fact that he was travelling some $250 \mathrm{kms}$ and at the age of twelve was leaving home for the first time to take up an apprenticeship:

Left home at Battersea at 5am. with Aunt Davies and Mr John Townsend. Coach ... left 'Bull and Mouth' Inn, Oxford Street at 7am., arrived Oxford at 1pm., stayed an hour for dinner and reached Hereford at 10pm. Slept at the Green Dragon Hotel. Rose at 6 am. on $24^{\text {th }}$, breakfasted, started by coach at $7 \mathrm{am}$. And arrived at Hope Gate. Thence to Mr Green, Hampton Mill. ${ }^{31}$ 
Although in some ways a world away from the majority twenty-first century expectation of rapid and uninterrupted travel by car or plane, current environmental concerns have also shifted attention towards movements for 'slow travel' which encapsulate some of the same characteristics as those found in previous centuries: travel which is overland, slow and with breaks to absorb the local environment and which, consequently, produces fewer carbon emissions. ${ }^{32}$ Although in the past most travelers experienced some interruptions and discomfort, the extent to which these were experienced was also class related. The rich travelled more quickly, more comfortably and more privately than the poor and, most crucially, they expected to do so. It is argued that while there certainly were significant changes in travel in the past - most notably technological change introducing rail, tram, car and plane travel - many other characteristics of mobility have changed little. There is, perhaps, less new about mobility than the concept of the new mobilities paradigm sometimes implies. What has changed, however, is that in contemporary society most of the population has attained, or at least adopted, the mobility expectations of the elite, and when transport systems fail to meet high expectations complaints ensue. This is explored in more detail below.

\section{Disrupted mobilities}

The reasons why everyday travel in the past was disrupted were largely similar to those experienced today. Problems occurred due to the weather, mishaps of various sorts, road conditions, personal illness, family circumstances or simple disorganization. These can be illustrated using the diary of Elizabeth Lee. As a young middle class woman she had both time and money to travel, and might be expected to be less affected by external factors than many other travelers. To some degree at least she was able to choose how she travelled and 
was rarely subject to strict time constraints. Her detailed diary demonstrates the ways in which everyday travel for someone of her class could be disrupted by mundane events.

As today, snow was a hazard that could reduce the ability to move freely, including local travel on foot around the immediate neighborhood. Elizabeth Lee recorded a number of occasions when she, or other family members, delayed or cancelled trips due to snow; and other occasions when journeys were completed with difficulty.

Went to Miss Cornish's party tonight. It commenced at 8. p.m. A lot of snow fell last night and it was awfully slippery outside. I could hardly get along. ${ }^{33}$

Today has been one of the worst days this winter. Frightful storm of snow and bitterly cold. Children had to stop at home from school. ${ }^{34}$

Dreadful day; snow again. Did'nt go out till tonight. Fred brought me home. ${ }^{35}$

However, for most of the time the weather was only a minor irritation which either delayed travel or made it less comfortable. As today, snow also had its compensations and could provide an attractive, even romantic, environment for walking: "Tonight went walk with Mr. M. It is lovely outside, snow everywhere, and moonlight over everything." ${ }^{36}$

Rail travel was frequent, both around Merseyside and further afield to visit friends or relatives and for holidays. Although most journeys were accomplished without difficulty there are numerous occasions when Elizabeth noted that a train was missed so they were late, or that visitors arrived late due to a missed, delayed or broken train. She rarely recorded precisely why trains were missed, but when she does the blame usually lies with herself (or others travelling with her) for disorganization or simply not allowing enough time. On a number of occasions Elizabeth was forced to take a different route to complete her journey, 
but such diversions usually generated only mild complaints. Selected examples are given below.

Mrs. Sykes took me to the Station this afternoon, missed my train. Awfully tired when I reached home. ${ }^{37}$

Came out in good time and went to station, but missed our train as Pa could'nt get the luggage out of office. Got into a Manchester Excursion train, had to go to M'chester and then nearly to Southport. Pa thought he would have a bother over the tickets but did'nt. Got home at 9.a.m. ${ }^{38}$

Ma and Arthur came home tonight, they were over two hours late, a train in front of theirs had broken down, so of course, they were delayed. ${ }^{39}$

The other factors that could seriously inhibit Elizabeth's ability to travel when and how she pleased were constraints imposed through her family. Her parents rarely directly constrained her movements (only once in 1888 was she banned from attending a ball because her father thought it unsuitable) but domestic crises and the need to do household chores, especially the lack of a servant, often interrupted Elizabeth's routine and forced her to delay or postpone travel. The following are a selection of representative diary entries.

Ma and I have been arranging for me to take the children out and mind them, one week, and herself the next week. So I shall be in the house the week between doing the work and sewing, and Ma the next. ${ }^{40}$

It is very wet this evening, and I had to stop at home because of that precious baby. ${ }^{41}$ Ma has been out all day so have had to mind baby. ${ }^{42}$ 
Nice day. Did'nt go to Church this morning. They all went a very long walk this afternoon, so I had to stay in to mind the house. ${ }^{43}$

Rhona Little, travelling in and around London in the 1930s, also experienced disruption due to the weather, though she rarely recorded travel problems that caused major inconvenience. One occasion when she had been staying with relatives near Kettering outside London she recorded that snow delayed her journey home and made her late for work, but as most of her everyday journeys were on London underground or over ground trains they were less likely to be disrupted by weather than more country routes:

We had just time to get to the station. When we arrived we found that the train was going to be late. We stayed in the refreshment room and Uncle got me some tea. We had to wait for $1 / 2 \mathrm{hr}$. I said goodbye and the train started. There was snow everywhere. There were telegraph wires down and a telegraph pole broken. The train went very slowly as it approached London. It did not reach St Pancras until $1 / 4$ to 12 . I was thus somewhat late for work. ${ }^{44}$

Longer distance and international travel in the past was of course more likely to suffer from delays and disruption, but such journeys were made relatively rarely. Rhona described in detail one of her return visits from London to Northern Ireland in July 1939. Apart from minor inconveniences the journey was unproblematic even though the total journey used five different forms of transport (walking, bus, train, boat, car) and at times there were minor inconveniences and delays. However, the impression given by the diary account is that these were normal and expected. Rhona's comments on the overnight crossing to Belfast are given as an example: 
The steerage berths are not so fine as the saloon. There were six in our room. There were two good ventilators. After the boat had started a woman with a little baby got a vacant berth. The baby did not cry all night, I slept for quite a while. The vibration is dreadful. I felt like a jelly. It did not roll much. I woke up early and it was quite roll$y^{45}$

Almost a century earlier in 1854 John James crossed the Atlantic to take up work with a mining company in Tennessee (USA). This was a long and arduous journey, potentially dangerous, and with many minor disruptions and inconveniences. However, as with Rhona Little, John James wrote about the journey in a very matter-or-fact style with the inconveniences, dangers and disruptions accepted as part of the experience. They clearly matched his expectations and although this was the first time he had crossed the Atlantic they were not seen as anything too problematic. The entry in his life history (written up from diaries) speaks for itself (the removed passages relate to long descriptions of US scenery and some reflection on fate of a semi-religious nature):

On the $6^{\text {th }}$ March 1854 I left my dear family for the United States of North America. Arrived at Liverpool Wednesday noon staying until Saturday. My first stay in a large town and was much struck by the ingenuity (?) of the place. Sailed by the SS Africa of the Cunard Line for New York. Had a very rough voyage, gale, head wind a great portion of the time - 17 days. The first Monday we had such a gale and heavy sea that we could scarcely stand. Cabin doors were broken in \& we got such a washing as was far from desirable, even to the lovers of salt water. We also had to encounter icebergs \& was in peril for some time from this cause. We sighted American land Monday 
afternoon March $27^{\text {th }}$. I was exceedingly ill for a week, sea sickness is a most distressing sensation. I was most fortunate in escaping being on board the "City of Glasgow" SS; that was not heard of again \& no doubt perished among icebergs. We were to sail on her but circumstances prevented; it was not for us. ... Stayed in New York from Tuesday morning till Thursday morning. New York is a fine city. ... On Thursday morning we started by rail for Tennessee, travelling via Philadelphia, Baltimore, Washington, Richmond, Weldon, Wilmington, Augusta, Atlanta, reaching Cleveland Tennessee on Monday evening - exactly four weeks from the time of leaving home. ... From the little growing town of Cleveland, Tennessee, we had to walk or ride near 40 miles to the mining district through mountain and river scenery. ... We have had to travel about 1,200 miles to reach this place, for the want of more direct communication. American roadway accommodation is now too well known to require description. It is well adapted to long journeys. ${ }^{46}$

When journeys are unexpectedly extended or disrupted today another normal expectation is that it is possible to contact family and friends to tell them where you are and to reassure then that all is well. In the past that was not possible and on an historical timescale the expectation of almost instant mobile communication almost anywhere is very recent (cell phones did not begin to be commonly available until the 1980 s). ${ }^{47}$ There is no comment made in the journal, but it can be speculated that if John James's relatives had known that he was due to sail on the SS City of Glasgow it is possible that news of her sinking reached the British press (and James's family) long before they received a letter from him telling of his safe arrival in the USA. ${ }^{48}$ However, it can also be suggested that in an era of slow communication, the worry of anticipating news from a traveler and the potential stress of feeling the need to communicate instantly with those left behind was less present. Thus for 
both those who travelled, and relatives who stayed at home, the expectation of slow, disrupted, travel with little news of progress to some degree could have eased concern.

Although communications over long distances were sometimes poor, from the $1860 \mathrm{~s}$, with the development of trans-Atlantic telegraphy and news agencies such as Reuters, they were potentially speeded up considerably. ${ }^{49}$ Furthermore, over shorter distances communications were in many ways very good. Within an urban area, with several posts a day, it was possible to send a letter in the morning and receive a reply by lunchtime to arrange a meeting for that evening. ${ }^{50}$ Although not quite the speed of text or e-mail communication it can be argued that the Victorian urban postal service allowed people to communicate in a not totally dissimilar way. Elizabeth Lee frequently corresponded with friends by post and used the post to arrange meetings at short notice (usually that evening or the following morning). Three examples illustrate this and, as the third extract demonstrates, a relatively quick response to letters was expected:

Had letter from L. Sanchez, asking me was I going to Communion in the morning, so I wrote and told her I was. ${ }^{51}$

..... Had a note from J.S.A. asking me to meet him, so went a jolly walk tonight, he has just come home from his holidays, has been to York and Whitby, he was nice. ${ }^{52}$ Sent such a letter to P. Young yesterday asking him the reason of his silence, got a letter from him this morning, saying he had been so dreadfully busy that he had'nt had time and asking me to meet him at 3.30.pm. in B'head- ..... ${ }^{53}$

\section{Concluding discussion}

Evidence for this paper has been drawn from a small number of diaries and life histories spanning a period of almost 100 years. It certainly cannot be claimed that these are in any 
way representative of any segment of society or any time period. Reliance on such fragmentary evidence is inevitable when researching a topic as mundane and unremarkable as everyday mobilities. Most everyday movement does not leave a record and even more rarely provides more than a bare statement that travel took place. The life writing used in this paper does, for the most part, allow us to begin to imagine the experience of travel in the past and to draw some conclusions about the role of delays, disruptions and inconveniences in travel over both short and long distances. As such, it provides an historical perspective on a number of issues central to the contemporary mobilities literature. ${ }^{54}$ I argue that everyday travel was commonplace over both long and short distances (though short trips were most frequent); that for the most part movement was unproblematic and that, most importantly, there was an expectation that journeys could be disrupted or delayed, and that travelling took a considerable time. This was a normal part of everyday travel practices. Delay caused minor inconvenience but, at least as recorded in these examples of life writing, it rarely merited prolonged comment or complaint.

By comparison, in the twenty-first century we have an expectation that travel will be quick and trouble free, and that if it goes wrong we have mobile communications that allow us to inform others and to make alternative arrangements. At the same time while most (though not all) travel modes have become faster, it can be argued that in some respects transport infrastructures and lifestyles have become less resilient. When mainly travelling on foot or horseback it is possible to negotiate most weather conditions even if it is at times slow and uncomfortable; by comparison the car is more easily prevented from moving by snow and ice. Heavy steam trains could also cope better with adverse weather conditions than modern high speed trains - for instance they did not rely on potentially fragile overhead power lines. For international travel planes are clearly more easily disrupted than boats that 
cope with all but the most extreme sea conditions. Thus as transport has become faster it has also lost resilience.

One key change is the switch of most travel from public to private forms of movement: almost universal access to the car has allowed most people to gain a level of privacy that was only available to the elite in the nineteenth century. ${ }^{55}$ However, this change has also altered levels of control and responsibility. Although one attraction of the car is to provide more freedom, including the ability to easily vary routes using modern navigational aids and mobile communications when delays occur, it also brings with it more responsibility. It can be argued that when the responsibility for travel lies with someone else (the train driver or airline pilot for instance) then there is a degree to which passengers accept delay because they cannot influence it. As a car driver delays that cannot be circumvented may cause even greater frustration because in theory you have more control but are temporarily unable to exert it. ${ }^{56}$ In addition, the volume of vehicles on the road has increased and, despite expansion of the road network and the construction of bypasses, this means that just one stranded vehicle can sometimes disrupt whole traffic systems. In the past a broken cart could be more easily moved or by-passed than a large lorry jack-knifed across a road. ${ }^{57}$ It can be suggested that as virtual mobility has increased rapidly in speed over the past three decades, physical mobility has remained largely static or, in some instances, has slowed (for example due to congestion). This apparent contradiction, and associated expectations, can lead to additional travel frustration, while the private car and mobile technologies may have contributed to a (mostly false) feeling that we can control situations better than was the case in the past.

Not only have transport systems lost resilience but also the same can be suggested for lifestyles: or at least that the nature of resilience has been reconstructed. It can be argued that in the past although most people did have busy lives, they did not feel the same pressure to 
complete a large number of tasks in a given time. Thus, if travel delays prevented some activities taking place they could be deferred to another time. For most people, and for most activities, the same is probably true today, but modern lifestyles appear to be constructed in such a way that many activities are crammed into a short space of time so that there is little room to adjust schedules and re-plan if travel delays occur. Thus it can be suggested that, in comparison with our diarists who accepted delays mostly with equanimity, modern lifestyles have been subject to a process of time-space compression and have become less adaptable and resilient. ${ }^{58}$ In some ways this is ironic because with more labor-saving devices and smaller families it could be argued that twenty-first century families are likely to have fewer essential demands on their time than, for instance, a family in the late-nineteenth century with five children and both parents working (as was common, for instance, in the textile districts of industrial Lancashire). ${ }^{59}$ However, this too is complex. It can be argued that for many middle class families domestic burdens increased in the twentieth century as servants became less affordable and less available, and housewives had to take on a greater range of domestic duties themselves. ${ }^{60}$ Although not amongst the poorest in society, most of the diarists mentioned were living in households without servants, and even in the Lee home the large family (12 children born to Elizabeth's mother) meant that both Mrs Lee and her daughter contributed extensively to domestic duties.

If we accept that such changes in the resilience of transport systems and lifestyles have occurred there remain some unanswered questions. For instance, when did these transitions take place and what caused both expectations to change and resilience to lessen? Did such changes occur evenly across society or were there social and spatial variations? Can changes in expectations be explained solely by the rise of faster forms of communication, or was the causality the other way round: expectations were increasing and new transport and communications technologies were developed and became widespread to meet these 
demands? Also, do new mobile communications really contribute to a less resilient society through an expectation of being able to resolve all problems instantly, or do they build additional (different) resilience through the opportunity for community-based social action organized through social networking sites $?^{61}$

Likewise, has there been a material change in the demands made on families such that lifestyles have become less resilient to disruption, or is this mainly a change in attitude towards what is perceived as normality? In the past some delay was normal and adjusting one's schedule to deal with that was expected. In the twenty-first century, although delays occur, they are not expected, and many people appear not to leave enough slack in a personal or household schedule to easily accommodate disruption. ${ }^{62}$ In particular, it can be suggested that attitudes to serious and potentially life-threatening disruptions may have changed. The diarists' accounts show a high degree of resignation and faith (often, though not always, religious) and an acceptance of risk and adversity. Today we usually expect to be able to control a situation and to prevent mishaps. Consequently we deal less well with the situation when disaster or disruption occurs. ${ }^{63}$ It is clear that such changes had not occurred by the 1930s and thus these topics have the potential for further investigation using oral history techniques. There is also scope for further research on the contemporary situation to test the extent to which the assertions outlined above actually hold true. 


\section{Biographical details}

Colin Pooley is Professor of Social and Historical Geography at Lancaster University (UK).

His research focuses on migration, mobility and social change in the past and the present.

Recent projects have examined twentieth-century changes in everyday mobility in Britain, and the barriers to walking and cycling in contemporary urban areas. He has published widely on these topics in both books and journal articles including Pooley, C., Turnbull, J. and Adams, M. (2005) A mobile century? Changes in everyday mobility in Britain in the twentieth century (Aldershot: Ashgate).

E-mail contact details: c.pooley@lancaster.ac.uk. 


\section{Footnotes}

${ }^{1}$. Thanks to the people who made available the unpublished diaries and life histories used in this paper. This paper draws on research from a number of previous projects. Particular thanks to Jean Turnbull, Mags Adams and Siân Pooley who contributed to this research at various times.

2 . Mimi Sheller and John Urry, "The new mobilities paradigm," Environment and Planning A, 38 no. 2 (2006): 207-26.

${ }^{3}$. For recent overviews of mobility studies see: Tim Cresswell, On the move: mobility in the modern Western world (London: Routledge, 2006); John Urry, Mobilities (Cambridge:

Polity, 2007); Peter Adey, Mobility (Abingdon: Routledge. 2010)

4. John Adams, The social implications of hypermobility (Paris: OECD, 1999). Available online at: http://john-adams.co.uk/wp-content/uploads/2006/00071363.PDF\#page=95;

Cresswell, On the move.

5. Thomas Birtchnell and Monika Büscher, "Stranded: an eruption of disruption" Mobilities 6 no. 1 (2011): 1-9.

${ }^{6}$. James Faulconbridge and Leslie Murray "Disrupting mobile urban lives" (paper presented at RGS annual international conference, Edinburgh, July $4^{\text {th }}, 2012$ ). 
7 . Vincent Kaufmann, Manfred. Bergman, Dominique Joye, "Motility: mobility as capital," International Journal of Urban and Regional Research 28 no. 4 (2004): 745-56; Kinglsey Dennis and John Urry, After the car (Cambridge: Polity, 2009); Anthony Elliott and John Urry, Mobile lives (London: Routledge, 2010).

${ }^{8}$. Kevin Hannam, Mimi Sheller and John Urry, "Mobilities, immobilities and moorings," Mobilities 1 no.1 (2006): 1-22; Peter Adey, "If mobility is everything then it is nothing: towards a relational politics of (im)mobilities,” Mobilities 1 no. 1 (2006): 75-94; David Bissell, “Animated suspension: waiting for mobilities,” Mobility 2 no.2 (2007): 277-98; Aharon Kellerman, "Potential mobilities," Mobilities 7 no. 1, (2012): 171-83.

${ }^{9}$. Erving Goffman, The presentation of self in everyday life (Garden City, NY: Doubleday, 1959); Erving Goffman, Stigma: notes on the management of spoiled identity (Englewood Cliffs, NJ: Prentice Hall, 1963); Michel De Certeau, The practice of everyday life (Berkley, Ca: University of California Press, 1988); Andreas Reckwitz, "Towards a theory of social practices: A development in cultural theorizing," European Journal of Social Theory 5 no. 2, (2002): 243-63; Theodore Schatzki, Karin Knorr Cetina and Eike von Savigny, The practice turn in contemporary theory (London: Routledge, 2001).

10 . Dominic Madell and Steven Muncer, "Control over social interactions: an important reason for young people's use of the internet and mobile phones for communication?" CyberPsychology and Behaviour 10 no. 1 (2007): 137-140; Yanging Cui and Virpi Roto, "How people use the web on mobile devices," Proceedings of the $17^{\text {th }}$ international conference on World Wide Web (WWW 2008), Beijing, China (2008): 905-914. 
11. Thomas Golob and Amelia Regan, "Impacts of information technology on personal travel and commercial vehicle operations: research challenges and opportunities," Transportation Research Part C 9 no. 2 (2001): 87-121; Mei-Po Kwan, "Mobile communications, social networks, and urban travel: Hypertext as a new metaphor for conceptualizing spatial interaction," The Professional Geographer 59 no. 4 (2007): 434-446.

12. Sangho Choo, Patricia Mokhtarian and Ilan Salomon, "Does telecommuting reduce vehicle miles traveled? An aggregate time series analysis for the US," Transportation 32 no. 1 (2005): 37-64; Patricia Mokhtarian, "If telecommunication is such a good substitute for travel, why does congestion continue to get worse?" Transportation Letters 1 no. 1 (2009): 117; Paul Hayes, "Information communication technology and international business travel: mobility allies?" Mobilities 5 no. 4 (2010): 547-64.

13. Avrom Fleishman, Figures of Autobiography: the Language of Self-Writing in Victorian and Modern England (Berkeley, Ca: University of California Press, 1983); Linda Peterson, Victorian Autobiography: the Tradition of Self-Interpretation (New Haven, CT: Yale University Press,1986); Heather Henderson, The Victorian Self: Autobiography and Biblical Narrative (Ithaca, NY: Cornell University Press, 1989); Valerie Sanders, The Private Lives of Victorian Women: Autobiography in Nineteenth-Century England (New York: St Martin's Press, 1989); Arthur Ponsonby, English Diaries: a Review of English Diaries from the Sixteenth to the Twentieth Century, with an Introduction on Diary Writing (London: Methuen, 1923); Amanda Vickery, The Gentleman's Daughter: Women's Lives in Georgian 
England (New Haven, CT: Yale University Press, 1998); Heather Creaton, Victorian Diaries: the Daily Lives of Victorian Men and Women (London: Mitchel Beazley, 2001).

14. Carol Dyhouse, Girls Growing Up in Late-Victorian and Edwardian England (London: Routledge, 1981); Carol Dyhouse, Feminism and the family in England 1880-1939 (Oxford: Blackwell, 1989); Leonore Davidoff and Catherine Hall, Family Fortunes: men and women of the English middle class, 1780-1850 (London: Routledge, 2002 (revised edition).

15. The diary is published in full as: Colin Pooley, Siân Pooley and Richard Lawton, eds., Growing up on Merseyside in the late-nineteenth century: the diary of Elizabeth Lee (Liverpool: Liverpool University Press, 2010).

${ }^{16}$. Unpublished diary. Copy given to the author by the diarist. For a fuller analysis see: Colin Pooley, "From Londonderry to London: Identity and sense of place for a Protestant Northern Irish woman in the 1930s," Immigrants and Minorities 18 nos. 2 and 3 (1999): 189-213; Colin Pooley, "Getting to know the city: the construction of spatial knowledge in London in the 1930s," Urban History 31 no. 2 (2004): 210-28.

${ }^{17}$. Unpublished Journal. Copy given to the author by the diarist's descendants. A copy of the journal can also be found in the Cornish Studies Library, Redruth, Cornwall, UK.

18. Unpublished life history. Copy given to the author by the diarist's descendants. For a fuller analysis see: Colin Pooley and Jean Turnbull, "Changing home and workplace in Victorian London: the life of Henry Jaques shirtmaker," Urban History 24 no. 2 (1997): 148-78. 
19. Unpublished diary. Copy given to the author by the diarist's descendants. This diary is quite sketchy and will be used only briefly.

${ }^{20}$. Life history of Henry Jaques (hereafter Jaques), April May, 1864.

${ }^{21}$ Jaques, 1875.

${ }^{22}$. Jaques, 1886.

23. For a discussion see Colin Pooley and Siân Pooley "Constructing a suburban identity: the everyday life of a young late-Victorian female," Journal of Historical Geography 36 no. 4 (2010): 402-10.

${ }^{24}$. Unpublished diary of Rhona Little (hereafter Little), Tuesday $1^{\text {st }}$ February, 1938.

${ }^{25}$. Diary of Elizabeth Lee (hereafter Lee), Wednesday $21^{\text {st }}$ January, 1891.

${ }^{26}$. Lee, Saturday $5^{\text {th }}$ March, 1892.

27. Transport for London website:

http://www.tfl.gov.uk/corporate/modesoftransport/londonunderground/1608.aspx (accessed June 20, 2012). 
28. This is Local London website:

http://www.thisislocallondon.co.uk/news/topstories/804876.london_cars_move_no_faster_th an_chickens/ (accessed June 20, 2012).

29. 20's Plenty for Us website: http://www.20splentyforus.org.uk/ (accessed June 20, 2012).

${ }^{30}$. Colin Pooley, Jean Turnbull and Mags Adams, A mobile century? Changes in everyday mobility in Britain in the twentieth century (Aldershot: Ashgate, 2005).

31 Diary of Joseph Yates $1826-96$, October $23^{\text {rd }} 1838$.

32. Janet Dickinson and Les Lumsdon, Slow travel and tourism (London: Earthscan, 2010); Jennie Germann-Molz, "Representing pace in tourism mobilities: staycations, slow travel and The Amazing Race," Journal of Tourism and Cultural Change 7 no.4, (2009): 270-86.

${ }^{33}$. Lee, Friday $8^{\text {th }}$ January, 1886.

${ }^{34}$. Lee, Monday $1^{\text {st }}$ March 1886.

35. Lee, Sunday $27^{\text {th }}$ March 1892.

${ }^{36}$. Lee, Saturday $9^{\text {th }}$ January 1992.

37. Lee, Monday $31^{\text {st }}$ October 1887. 
${ }^{38}$. Lee, Thursday $25^{\text {th }}$ October 1888.

${ }^{39}$. Lee, Monday $18^{\text {th }}$ August 1890.

${ }^{40}$. Lee, Monday $14^{\text {th }}$ January 1884.

${ }^{41}$. Lee, Sunday $19^{\text {th }}$ July 1885.

${ }^{42}$. Lee, Wednesday $19^{\text {th }}$ June 1889.

${ }^{43}$. Lee, Sunday $20^{\text {th }}$ July 1890.

${ }^{44}$. Little, Thursday $26^{\text {th }}$ January 1939.

${ }^{45}$. Little, Saturday $15^{\text {th }}$ to Sunday $16^{\text {th }}$ July 1939.

46. Unpublished life history of John James, entries for March/April 1854.

47. Sameer Kumar and Christopher Zahn, "Mobile communications: evolution and impact on business operations," Technovation 23 no. 6 (2003): 515-520.

${ }^{48}$. The City of Glasgow was first reported 32 days overdue in The Times on $15^{\text {th }}$ April 1854 , although sightings of her wreckage were not reported until August $31^{\text {st }}$. If John James had 
written home as soon as he arrived in New York his letter would not have reached Cornwall until late April, sometime after the first reports that the City of Glasgow was overdue. Of course it is not known if his relatives would read a national newspaper. He may also have written home from Liverpool telling them he was not to sail on the City of Glasgow.

${ }^{49}$. Ken Beauchamp, History of telegraphy (Stevenage: The Institution of Engineering and Technology, 2001); Donald Read, "Reuters: news agency of the British Empire," Contemporary Record 8 no. 2 (1994): 195-212.

50. Martin Daunton, Royal Mail: the Post Office since 1840 (London: Athlone Press, 1985).

${ }^{51}$. Lee, Saturday $24^{\text {th }}$ April 1886.

52. Lee, Wednesday $20^{\text {th }}$ August 1890.

${ }^{53}$. Lee, Saturday $4^{\text {th }}$ June 1892 . It had been almost two weeks since she had heard from Mr Young.

54 . Cresswell, On the move; Urry, Mobilities; Adey, Mobility.

55 . Sean O'Connell, Class, gender and motoring 1890-1939 (Manchester: Manchester University Press, 1998); Peter Merriman, Driving spaces: a cultural historical geography of England's M1 motorway (Oxford: Blackwell, 2007); Jim Conley and Arlene Tigar Mclaren 
eds., Car troubles: critical studies of automobility and auto-mobility (Farnham: Ashgate, 2009).

56. Icek Ajzen, "Perceived behavioural control, self efficacy, locus of control, and the theory of planned behavior," Journal of Applied Social Psychology 32 no. 4 (2002) 665-83.

57. Brad Allenby and Jonathan Fink, "Towards inherently secure and resilient societies," Science, 309 no. 5737 (August 2005): 1034-1036; Susan Christopherson, Jonathan Michie and Peter Tyler, "Regional Resilience: theoretical and empirical perspectives," Cambridge Journal of Regions, Economy and Society 3 no. 1 (2010): 3-10. Part of a special issue on 'The Resilient Region’ pp1-167.

58 . David Harvey, The condition of postmodernity (Oxford: Blackwell, 1989).

59. Mary Rose, The Lancashire cotton industry: A history since 1700 (Preston: Lancashire County Books, 1996); John Walton, Lancashire: a social history, 1558-1939 (Manchester: Manchester University Press, 1987).

${ }^{60}$. Ruth Cowan, “The 'industrial revolution' in the home: household technology and social change in the $20^{\text {th }}$ century," Technology and Culture 17 no. 1 (1976): 1-23; Ruth Cowan, More work for mothers: the ironies of household technology from the Open hearth to the microwave (New York: Basic Books, 1983); Lucy Delap, Knowing their place. Domestic service in twentieth century Britain (Oxford: Oxford University Press, 2011); Lucy Delap, 
"Housework, housewives and domestic workers: twentieth-century dilemmas of domesticity," Home Cultures 8 no. 2 (2011): 189-209.

${ }^{61}$. Sung-Yueh Perng et al., "Peripheral response: microblogging during the 22/7/2012 Norway attacks," Proceedings of the $9^{\text {th }}$ international ISCRAM conference (Vancouver, April 2012); Emma Tonkin, Heather Pfeiffer and Greg Tourte, "Twitter, information sharing and the London riots?" Bulletin of the American Society for Information Science and Technology 38 no. 2 (2012): 49-57.

62. Dick Ettema and Harry Timmermans, "Space-time accessibility under conditions of uncertain travel times: theory and numerical simulations" Geographical Analysis 39 no. 2 (2007): 217-240.

63. Richard Helmstadter and Bernard Lightman, eds., Victorian faith in crisis, Essays on continuity and change in nineteenth-century religious belief (Stanford, Ca: Stanford University Press, 1990); Steve Bruce, "Religion in Britain at the close of the $20^{\text {th }}$ century: a challenge to the silver lining perspective," Journal of Contemporary Religion 11 no. 3 (1996): 261-275; Alasdair Crockett and David Voas, "Generations of decline: religious change in $20^{\text {th }}$ century Britain," Journal for the Scientific Study of Religion 45 no. 4 (2006): 567-584. 